\title{
THE INFLUENCE OF VOCABULARY AND GRAMMAR MASTERYON \\ THE STUDENTS' WRITING SKILL AT YOGYAKARTA \\ STATE UNIVERSITY
}

\author{
Saptin Dwi Setyo Hastuti \\ A Lecturer at Sekolah Tinggi Pariwisata AMPTA Yogyakarta
}

\begin{abstract}
This study aims to investigate the influence of (1) the students' vocabulary mastery on their writing skill, (2) the students' grammar mastery on their writing skill and(3) the students' vocabulary and grammar mastery on their writing skill at Yogyakarta State University. This research was an ex-post facto. The population comprised the third semester students of Pendidikan Bahasa Inggris (PBI) study program at the Languages and Arts Faculty, Yogyakarta State University in the academic year 2013/2014. Therefore, this study showed that (1) vocabulary mastery positively influenced the students' writing skill, (2) grammar mastery positively influenced the students' writing skill, and (3) vocabulary and grammar mastery positively influenced the students' writing skill.
\end{abstract}

Keywords: vocabulary mastery, grammar mastery, and writing skill.

\section{INTRODUCTION}

The official instruction of Dirjen Dikti 152/E/T/2012 released on January, 27 2012 about 'Publikasi Karya Ilmiah' says that the under graduate students have to produce an academic paper and publish it in one of the national journals. This instruction is applied due to the lack of published academic papers. One benefit that can be taken from this instruction is that it may reduce the practice of plagiarism, remembering that academic papers publish in the journal should be freed from plagiarism.

The plagiarism practice may influence not only one's papers originality but also her/his writing skill. In writing, one is not only dealing with generating ideas but also organizing ideas by constructing words into meaningful sentences. Moreover, the degree of difficulty in writing will be multiplied when one is writing in a foreign language, in this case is English. Richards and Renandya
(2002) say that "writing is the most difficult skill for foreign language learner to master, which its difficulties are not only laying in organizing and generating ideas but also in translating those ideas into readable text".

Unlike speaking, in writing, one has to be able to use the language correctly because writing is not supported by non-linguistic features such as intonation or gesture. Thus, as Davies and Pearse (2000) say that writing requires more carefully constructed sentences, a greater amount of vocabulary, and grammar. One will be able to choose the appropriate words to use if she/he has sufficient vocabulary. The great amount of vocabulary that she/he has will provide her/ him with wider range of vocabulary choices.

Furthermore, Hinkel (2011) noted that one's vocabulary and grammar level might disadvantage her/his writing skill. He also said that there are a big difference between the native writings and non-native writings. 
Therefore, according to this conclusion, there is possibility that the lexical and syntactical properties of PBI study program students, who are non-native learners, may influence their writing skill.

\section{LITERATURE REVIEW}

Writing, for language learners, is the most difficult skill than the other skills. In writing, one is not only dealing with generating ideas but also organizing ideas by constructing words into meaningful sentences. Moreover, the degree of difficulty in writing will be multiplied when one is writing in a foreign language, in this case is English. Richards and Renandya (2002) say that "writing is the most difficult skill for foreign language learner to master, which its difficulties are not only laying in organizing and generating ideas but also in translating those ideas into readable text". Organizing ideas is an important key in writing. Unlike speaking, writing is not limited to time and space. Knapp and Watkins (2005) describe that "writing takes language out of the constraints and immediacy of time and arranges it hierarchically". Therefore, in writing, one may explore her/his ideas or information and draw them into the form of written language without cutting the details during the process.

Furthermore, the organized ideas or information might not be transferred correctly if one does not know how to use the language. According to Davies and Pearse (2000), writing not only involves lowlevel skills of handwriting/typing, spelling, constructing grammatical sentences, and punctuating; but also high-level cognitive skills of processing, selecting, organizing the ideas and information into rational sequence, arranging the sequence, drafting the sequence in the form of paragraphs, editing the draft, and writing the final product.

Along with Davies and Pearse, Flynn and Stainthorp (2006) define that writing involves one's cognitive skill. It means that one must be careful in putting her/his ideas into the written form so that the ideas in her/his mind are not distorted. Thus, in order to avoid the distortion, establishing context in writing is important. It is a kind of tools for helping the reader to catch the meaning of one's writing. Davies and Pearse (2000) explain that creating context, references, and connection of messages are important in written language and it requires grammar completeness, a greater amount of vocabulary, and the use of grammatical structure of written language. Those are the reasons why one has to have an adequate vocabulary and grammar mastery so that the distortion of the transferred ideas can be avoided.

According to Hiebert and Kamil (2005), vocabulary is the knowledge of words' meaning. In accordance, Strickland et.al (2007) says that learning vocabulary is not simply as learning words, it is because words are not only helping one in naming things but also help her/him to think and talk about ideas. Therefore, in learning words one should understand the meaning of the words. However, knowing the form of a word and its meaning is not enough. Nation (2001) explains that one not only needs to know the form of a word and its meaning, she/he needs to be able to connect those two. Thus, one can be said mastering a word when she/ he also knows how to choose a word that can represent what she/he is referring.

On the other hand, as mentioned before, grammar also plays an important role in writing. Wasow (2003) and Donoghue (2009) define grammar as a set of abstract rules of communication and the underlying structure of language that evolved naturally and the native speakers of the language master it without explicit instruction. Although learning grammar is a natural one, it is possible for one to learn other languages. It is because every language has its own grammar that can be learnt by language 
learners.

\section{RESEARCH METHOD}

This research was applying an ex - post facto design in which the factors influencing the current state occurred in the past. It means that there was no manipulation on both of dependent or independent variables. Therefore, the external variables of the research could not be controlled. In order to control them, it was necessary to conduct statistical control by having multiple regressions and partial correlation analysis. This research involved two independent variables; they were vocabulary mastery (X1) and grammar mastery (X2). It also involved one dependent variable that is students' writing skill (Y). The objectives of this research were to find whether the vocabulary mastery influenced the students' writing ability or not, the grammar mastery influenced the students' writing ability or not, or both of vocabulary and grammar mastery influenced the students' writing ability or not. The design of this research is as follow,

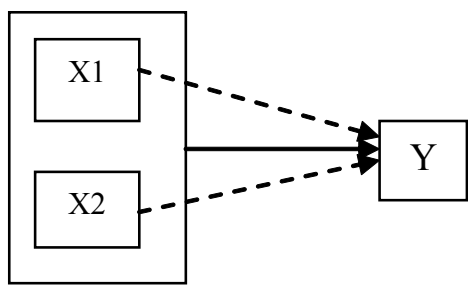

Figure 1 The Influence of Independent Variables on Dependent Variable

\section{RESULTS AND DISCUSSION}

The Influence of Vocabulary on the Students' Writing Skill

The influence of vocabulary mastery on the PBI study program students' writing skill was shown by this research result. From Table $\mathbf{1}$ can be seen that the significance value/ $\rho(0.002)$ is lower than $\alpha(0.005)$. It means that the vocabulary mastery influenced the PBI study program students' writing skill.

Table 1. The ANOVA of Vocabulary Mastery on the Students' Writing Skill

\begin{tabular}{|c|c|c|c|c|c|c|}
\hline \multicolumn{2}{|c|}{ Model } & Sum of Squares & df & Mean Square & $\mathbf{F}$ & Sig. \\
\hline \multirow{3}{*}{$\frac{1}{1}$} & Regression & 564.971 & 1 & 564.971 & 11.129 & $.002^{\mathrm{a}}$ \\
\hline & Residual & 1726.105 & 34 & 50.768 & & \\
\hline & Total & 2291.076 & 35 & & & \\
\hline
\end{tabular}

Furthermore, the influence of vocabulary mastery on the writing skill is shown in Table 2. It shows that the influence of vocabulary mastery on the writing skill was only $24.7 \%$. In addition, this shows that if the students' vocabulary mastery is high, then their writing skill is high too. On the other hand, when the students' vocabulary is low, then their writing skill is low too.

Although the influence was low, vocabulary mastery and writing skill had positive correlation. This can be seen in this following table from Table 3 that the Standardized Coefficients Beta is 0.497 . This value means that vocabulary mastery had positive correlation with writing skill.

Table 2. The Model Summary of Vocabulary Mastery on the Students' Writing Skill

\begin{tabular}{lllll}
\hline Model & $\mathbf{R}$ & $\mathbf{R}$ Square & Adjusted R Square & Std. Error of the Estimate \\
\hline $1 \quad .497^{\mathrm{a}}$ & .247 & .224 & 7.12515 \\
\hline a. Predictors: (Constant), Vocabulary & \\
b. Dependent Variable: Writing
\end{tabular}


Table 3. The Coefficients of Vocabulary Mastery on the Students' Writing Skill

\begin{tabular}{lllllll}
\hline \multirow{2}{*}{ Model } & \multicolumn{2}{l}{$\begin{array}{l}\text { Unstandardized } \\
\text { Coefficients }\end{array}$} & \multicolumn{2}{l}{$\begin{array}{l}\text { Standardized } \\
\text { Coefficients }\end{array}$} & \multirow{2}{*}{ S } & \multirow{2}{*}{ Sig. } \\
\cline { 2 - 6 } & $\mathbf{B}$ & Std. Error & Beta & & \\
\hline 1 & (Constant) & 44.912 & 7.741 & & 5.802 & .000 \\
\cline { 2 - 7 } & Vocabulary & .985 & .295 & .497 & 3.336 & .002 \\
\hline
\end{tabular}

a. Dependent Variable: Writing

These results are the proofs that vocabulary plays an important role in writing. One will find some difficulties in writing if she/he does not know the words that will represent her/his ideas. Knowing the form of words, the meaning, and the use will help one in translating her/his ideas into a good piece of writing. If one writes without knowing what words are supposed to use, it may lead to distortion on the meaning of the ideas. It is like what has been said by Strickland et.al (2007) that learning vocabulary is not simply as learning words because words not only help one in naming things but also help her/him to think and talk about ideas. This research finding was in line with the research conducted in Greater Vancouver public secondary school by Lee. Lee (2003) found that ESL learners had to be shown (i) how to use their receptive or recognition vocabulary and new vocabulary in the production task, and (ii) how the lexical variation and the lexical variation frequency affect the quality of their writing. Furthermore, Nation (2001) and Sousa (2011) say that vocabulary choice is a sign that the writer has adopted the discourse of certain community and a good piece of writing depends on the writer's vocabulary choices. It can be concluded that one will be able to produce a good piece of writing when she/he is able to use her/his vocabulary appropriately. It means that she/he should recognize what words she/he supposes to use in a certain context, which requires a great amount of vocabulary. Moreover, the research also shows the PBI study programs had high vocabulary mastery. It can be seen in this following table,

Table 4.The Frequency Distribution of Vocabulary Mastery

\begin{tabular}{|c|c|c|c|}
\hline Interval & Category & Frequency & $\%$ \\
\hline $32.03-38.15$ & $\begin{array}{c}\text { Very High } \\
(\bar{X}+1.5 S D \leq X<\bar{X}+3 S D)\end{array}$ & 1 & 2.78 \\
\hline $25.91-32.03$ & $\begin{array}{c}\text { High } \\
(\bar{X} \leq X<\bar{X}+1.5 S D)\end{array}$ & 19 & 52.78 \\
\hline $19.79-25.91$ & $\begin{array}{c}\text { Fair } \\
(\bar{X}-1.5 S D \leq X<\bar{X})\end{array}$ & 13 & 36.11 \\
\hline $13.67-19.79$ & $\left.\begin{array}{l}\text { Low } \\
(\bar{X}-3 S D \leq X\end{array} \bar{X}-1.5 S D\right)$ & 3 & 8.33 \\
\hline
\end{tabular}

Although their vocabulary mastery was considered high, it is necessary for them to increase their vocabulary mastery in order to improve their writing skill. Listening and reading can help them in gathering new words since the vocabulary input is drawn from listening and reading. As Nation (2001), Djiwandono (2008), and Pikulski and Templeton (2004) say that one receives set of words from listening or reading and she/he has to try to grasp the meaning or the ideas.

\section{The Influence of Grammar Mastery on the Students' Writing Skill}

The influence of vocabulary mastery on the PBI study program students' writing skill was shown by this research result. This following table shows the result of simple regression analysis, 
Table 5. The ANOVA of Grammar Mastery on the Students' Writing Skill

\begin{tabular}{|c|c|c|c|c|c|}
\hline \multirow{2}{*}{$\begin{array}{l}\text { Model } \\
\text { Regression }\end{array}$} & \multicolumn{2}{|c|}{ Sum of Squares } & \multicolumn{2}{|c|}{ Mean Square } & \multirow{2}{*}{$\begin{array}{r}\text { Sig. } \\
.000^{\mathrm{a}}\end{array}$} \\
\hline & 1041.804 & 1 & 1041.804 & 28.354 & \\
\hline Residual & 1249.272 & 34 & 36.743 & & \\
\hline Total & 2291.076 & 35 & & & \\
\hline
\end{tabular}

a. Predictors: (Constant), Grammar, b. Dependent Variable: Writing

Table 5 shows that the significance value/ $\rho(0.000)$ is lower than $\alpha(0.005)$. It means that the grammar mastery really influenced students' writing skill. Furthermore, the influence of vocabulary mastery on the writing skill can be seen from the value of $\mathrm{R}$ Square. Table $\mathbf{6}$ shows that the influence of vocabulary mastery on the writing skill was $45.5 \%$. This result shows that if the students' grammar mastery is high, then their writing skill is high too. On the other hand, when the students' grammar mastery is low, then their writing skill is low too. Beside grammar mastery influenced the writing skill, grammar mastery also had positive correlation with writing skill. It can be seen from Table 7 that the Standardized Coefficients Beta is 0.674. This value means that grammar mastery had positive correlation with writing skill.

Table 6. The Model Summary of Grammar Mastery on the Students' Writing Skill

\begin{tabular}{lllll}
\hline Model & $\mathbf{R}$ & $\mathbf{R}$ Square & Adjusted R Square & Std. Error of the Estimate \\
\hline $1 \quad .674^{\text {a }}$ & .455 & .439 & 6.06162 \\
\hline a. Predictors: (Constant), Grammar & \\
b. Dependent Variable: Writing
\end{tabular}

Table 7. The Coefficients of Vocabulary Mastery on the Students' Writing Skill

\begin{tabular}{|c|c|c|c|c|c|c|}
\hline \multicolumn{2}{|c|}{ Model } & \multicolumn{2}{|c|}{$\begin{array}{l}\text { Unstandardized } \\
\text { Coefficients }\end{array}$} & \multirow{2}{*}{$\begin{array}{l}\text { Standardized } \\
\text { Coefficients } \\
\text { Beta } \\
\end{array}$} & \multirow[t]{2}{*}{$t$} & \multirow[t]{2}{*}{ Sig. } \\
\hline \multirow{3}{*}{1} & & & Stu. CIIIUI & & & \\
\hline & (Constant) & 38.427 & 6.095 & & 6.305 & .000 \\
\hline & Grammar & 1.136 & .213 & .674 & 5.325 & .000 \\
\hline
\end{tabular}

a. Dependent Variable: Writing

These results are the evidence that grammar mastery plays important role in writing. One has to know the rule how to arrange words in the correct order. It is because if one does not know the grammar, it is impossible for her/him to produce a good piece of writing. In another word, it is impossible for the reader to grasp the idea of one's writing if she/he cannot produce a good piece of writing, which requires the correctness of the grammar use. The fact that grammar mastery might influence the writing skill was also proven by the research result conducted in China. Shen (2012) concluded that teaching language would not be successfully conducted without grammar instruction and the purpose of writing could not be achieved without correct use of the grammatical concept. Another research conducted by Fatemi (2008) who found that the writing failures of Iranian sophomores was the result of the interference of their first language grammar. These research findings are the evidence that grammar mastery really influences the writing skill. The fact that grammar mastery had positive correlation with writing skill means that writing cannot be separated from grammar. It is supported by Nation (2001) who claims that writing with grammar help involves guided compositions 
which are based on special grammar problems. It means that grammar helps one to compose her/his ideas into meaningful messages. By this mean, it can be concluded that one's grammar mastery influences her/ his writing skill. Furthermore, this research revealed that most of the PBI students fairly mastered the grammar. The evidence can be seen in this following table,

Table 8.The Frequency Distribution of Grammar Mastery

\begin{tabular}{|c|c|c|c|}
\hline Criteria & Category & Frequency & $\%$ \\
\hline $35.36-42.56$ & $\begin{array}{c}\text { Very High } \\
(\bar{X}+1.5 S D \leq X<\bar{X}+3 S D)\end{array}$ & $\mathrm{F}_{2}$ & 8.33 \\
\hline $28.16-35.36$ & $\begin{array}{c}\text { High } \\
(\bar{X} \leq X<\bar{X}+1.5 S D)\end{array}$ & 14 & 38.89 \\
\hline $20.96-28.16$ & $\begin{array}{c}\text { Fair } \\
(\bar{X}-1.5 S D \leq X<\bar{X})\end{array}$ & 17 & 47.22 \\
\hline $13.76-20.96$ & $\left(\bar{X}-3 S D \leq X<\frac{\text { Low }}{<}-\bar{X}-1.5 S D\right)$ & 2 & 5.55 \\
\hline
\end{tabular}

As mentioned in introduction, writing requires correct grammatical concept and writing in non-native language might be tricky since one has to deal with the grammar difference. Thus, it is necessary for the PBI students to learn more about English grammar if they wish to increase their writing skill.

\section{The Influence of Vocabulary and Grammar Mastery on the Students' Writing Skill}

According to the previous discussions, it was clear that vocabulary mastery influenced and had positive correlation with the writing skill as well as the grammar mastery. According to those result, it can be said that one needs sufficient vocabulary mastery and grammar mastery in order to produce a good piece of writing. The data show that, together, both of vocabulary and grammar mastery influenced the writing skill. The influence of vocabulary and grammar mastery on the PBI study program students' writing skill was shown by this research result. . This following table shows the result of multiple regressions analysis,

Table 9. The ANOVA of Vocabulary and Grammar Mastery on

the Students' Writing Skill

\begin{tabular}{|c|c|c|c|c|c|c|}
\hline \multicolumn{2}{|c|}{ Model } & \multirow{2}{*}{$\begin{array}{l}\text { Sum of Squares } \\
1148.139\end{array}$} & \multirow{2}{*}{$\begin{array}{l}\text { df } \\
2\end{array}$} & \multirow{2}{*}{$\begin{array}{l}\text { Mean Square } \\
574.069\end{array}$} & \multirow{2}{*}{$\begin{array}{l}\mathbf{F} \\
16.575\end{array}$} & \multirow{2}{*}{$\begin{array}{l}\text { Sig. } \\
.000\end{array}$} \\
\hline 1 & Regression & & & & & \\
\hline & Residual & 1142.937 & 33 & 34.634 & & \\
\hline & Total & 2291.076 & 35 & & & \\
\hline
\end{tabular}

Table 9 shows that the significance value $/ \rho$ $(0.000)$ is lower than $\alpha(0.005)$. It means that the vocabulary and grammar mastery really influenced students' writing skill. Furthermore, the influence of vocabulary and grammar mastery on the writing skill can be seen from the value of Adjusted R Square. Table $\mathbf{1 0}$ shows that the influence of vocabulary and grammar mastery on the writing skill was $47.1 \%$. It means that the influence of vocabulary and grammar mastery on the writing skill was $47.1 \%$ and the rest was influenced by the other factors that were not being discussed in this research. This result means that if the students' vocabulary and grammar mastery 
were high, then their writing skill is high too. Beside vocabulary and grammar mastery influenced the writing skill, both of them also had positive correlation with writing skill. It can be seen from the value of R Square Change in Table 11. Therefore, the value of correlation coefficient between vocabulary and grammar mastery, which was
$50.1 \%$, shows that they positively correlated with the writing skill. This value shows that the correlation is quite strong. In addition, this research also showed the influence of vocabulary and grammar mastery on the writing skill. It can be seen in this following table,

Table 10. The Model Summary of Vocabulary and Grammar Mastery on the Students' Writing Skill

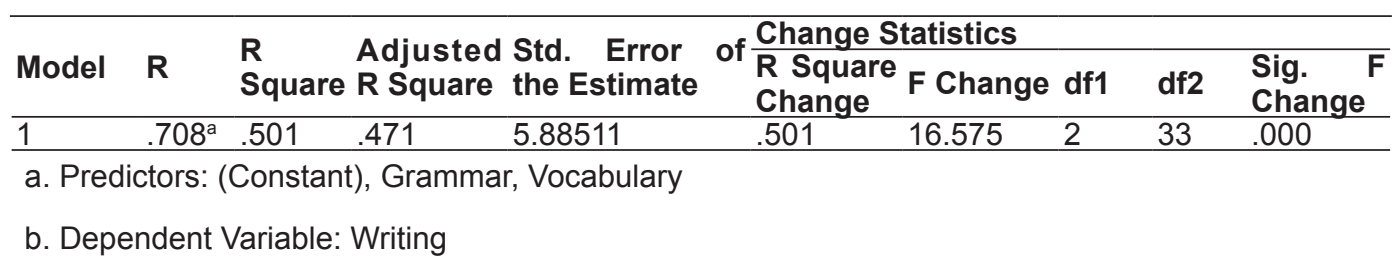

Table 11. The Coefficients of Vocabulary Mastery on the Students' Writing Skill

\begin{tabular}{|c|c|c|c|c|c|c|c|}
\hline \multirow{2}{*}{\multicolumn{2}{|c|}{ Model }} & \multicolumn{2}{|c|}{$\begin{array}{l}\text { Unstandardized } \\
\text { Coefficients }\end{array}$} & \multirow{2}{*}{$\begin{array}{l}\text { Standardized } \\
\text { Coefficients } \\
\text { Beta } \\
\end{array}$} & \multirow[t]{2}{*}{$t$} & \multirow[t]{2}{*}{ Sig. } & \multirow{2}{*}{$\begin{array}{l}\text { C o I I i n e a r i t y } \\
\text { Statistics } \\
\text { Tolerance VIF }\end{array}$} \\
\hline & & & Std. Error & & & & \\
\hline \multirow[t]{3}{*}{1} & (Constant) & 31.192 & 7.215 & & 4.323 & .000 & \\
\hline & Vocabulary & .479 & .273 & .241 & 1.752 & .089 & 1.256 \\
\hline & Grammar & .953 & .232 & .565 & 4.103 & .000 & 1.256 \\
\hline
\end{tabular}

a. Dependent Variable: Writing

From Table $\mathbf{1 1}$ can also be drawn the regression equation based on the unstandardized coefficient beta $(\beta)$ is:

$$
\widehat{Y}=31.192+0.479 \mathrm{X} 1+0.953 \mathrm{X} 2
$$

From the regression equation, it can be seen that the constant coefficient is 31.193. It means when vocabulary or grammar mastery are not involved in the equation, the students' writing skill constant is 31.193 . Furthermore, the vocabulary mastery coefficient is 0.479 . It means that if the vocabulary increased one point, while grammar mastery remained stable, the writing skill would increase $0.479 \%$. Last, the grammar mastery coefficient is 0.953 . It means that if the grammar mastery increased one point, while the vocabulary remained stable, the writing skill would increase $0.953 \%$.
These results were the proofs that vocabulary and grammar mastery play important role in writing since it is impossible for one to write without knowing what words she/he supposes to use and how she/ he will construct the words into sentences. Thus, one needs to master both vocabulary and grammar because writing is the most complicated than the other skills, such as listening, reading, and speaking. Davies and Pearse (2000) describe that creating context, references, and connection of messages are important in written language and it requires grammar completeness, a greater amount of vocabulary, and the use of grammatical structure of written language. The previous researches also showed that both vocabulary and grammar mastery influenced the writing skill. Hinkel (2011) summarized 
those research results and concluded that the English non-native writers' skill level in vocabulary and grammar disadvantage the quality of their formal prose since the findings showed that the mistakes on vocabulary choice and grammar use were high. Additionally, Srichanyachon (2011) found that the EFL students had difficulties in making grammatical appropriate sentences and they could only correct the small mistakes on spelling or capitalization. Accordingly, he concluded that the students did not learn writing as a subject systematically, so they did not know how to use appropriate words and make correct sentences. Other research conducted by Tajzadeh, Khodabandehlou, and Jahandar (2013) showed that grammar instruction had positive effects on the Iranian EFL learner's writing skill. Based on these findings, it can be said that vocabulary and grammar mastery truly influenced the quality of a piece of writing. Here, the influence of vocabulary and grammar mastery on the writing skills can be represented by figure 2 .

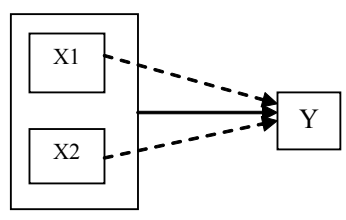

Figure 2. The Relationship between Vocabulary and Grammar Mastery on the Students' Writing Skill

Note:

X1 : first independent variable (vocabulary mastery)

X2 : second independent variable (grammar mastery)

Y : dependent variable (writing skill)

$\longrightarrow$ : the influence of the independent variables on dependent variable

$\rightarrow-\rightarrow$ : the influence of an independent variable on dependent variable

Furthermore, this research also revealed that most of PBI study program students' writing skill was merely good. It can be seen in this following table,

Table 12. The Frequency Distribution of Writing Skill

\begin{tabular}{cccc}
\hline Criteria & Category & Frequency & \% \\
\hline $82.56-94.70$ & Very Good & 3 & 8.33 \\
& $(\bar{X}+1.5 S D \leq X<\bar{X}+3 S D)$ & & \\
$70.43-82.56$ & Good & 17 & 47.22 \\
$58.30-70.43$ & $(\bar{X} \leq X<\bar{X}+1.5 S D)$ & & 38.89 \\
& $\quad$ Fair & 14 & \\
$46.16-58.30$ & $(\bar{X}-1.5 S D \leq X<\bar{X})$ & & 5.55 \\
\hline
\end{tabular}

Furthermore, this research also revealed that most of PBI students' writing skill was merely good. The findings also showed that vocabulary and grammar mastery influenced and positively correlated with the writing skill. As mentioned previously, a great amount of vocabulary may provide one's with wider vocabulary choices. However, one's should have better concept of grammar so that she/he is not only be able to make correct grammatical sentences but also meaningful sentences. Thus, it is necessary for the students to improve their writing skill through increasing their vocabulary and grammar mastery.

\section{Conclusion}

Considering to the result, it had been proven that vocabulary and grammar mastery influenced the students' writing skill. The results show that vocabulary mastery influenced the writing skill. Moreover, from the result can be seen that between 
vocabulary mastery and writing skill had positive correlation. It means that when the vocabulary mastery is getting higher, the writing skill is also getting higher. The results also shows that grammar mastery influenced the writing skill and they had positive correlation. It means that when the grammar mastery is getting higher, the writing skill is also getting higher. Furthermore, the results also reveal that vocabulary and grammar mastery influenced on the students' writing. Moreover, the results also show that vocabulary and grammar mastery had positive correlation with writing skill. It means that the vocabulary and grammar mastery had stronger influence on the students' writing skill than when they were separated.

This research is far from perfection. It is because the collected data from vocabulary test, grammar test, and writing assignment can be influenced by the other variables outside the research variables. Furthermore, the condition of the students or the situation when the tests took place might influence the results as well. Moreover, the English background of the students before they joined English Education Department might could not be controlled. As the result, there is possibility that it also influenced the results.

\section{REFERENCES}

Davies, P., \& Pearse, E. 2000. Succes in English teaching. Oxford: Oxford University Press.

S, Djiwandono. 2008. Tes bahasa: Pegangan bagi pengajar bahasa. Jakarta: PT Indeks.

Donoghue, M. R., 2009. Language Arts. USA: Sage Publication Inc.

Fatemi, M. A. 2008. The relationship between writing competence, language proficiency, and grammatical errors in the writing of Iranian TEFL sophomores. Accessed on 9 November 2013 from http://search.proquest. com/docview/1081337732/141A0869 $\underline{\text { EAF2E47D496/6? accountid }=31324}$

Flynn, N., \& Stainhorp. R. 2006. The learning and teaching of reading and writing. England: Whurr publisher Limited.

Hinkel, E. 2011. What research on second language writing tells us and what it doesn't. In E. Hinkel (Eds.), Handbook of Research in Second Language Teaching and Learning Volume II (pp 523 - 538). New York: Routledge.

Kamil, M. L., \& Hiebert, E. H. 2005. English teaching and learning vocabulary: Bringing research to practice. New Jersey: Lawrence Erlbaum and Associates.

Knapp, P., \& Watkins, M. 2005. Genre, text, grammar: Technologies for teaching and assessing writing. Australia: New South Wales Press Ltd.

Lee, S. H. 2003. ESL learners' vocabulary use in writing and the effects of explicit vocabulary instruction [Electronic version]. System, 31, $527-561$.

Nation, I. S. P. 2001. Learning vocabulary in another language. United Kingdom: Cambridge University Press.

Pikulski.J.J.,\&Templeton,S. 2004. Teaching and developing vocabulary: Key to long-term reading success, Accessed on 31 September 2013 from http:// www.eduplace.com/marketing/nc/pdf/ author pages.pdf

Richards, J. C., \& and Renandya, W. A. (Eds.). 2002. Methodology in language 
teaching: An anthology of current practice. United Kingdom: Cambridge University Press.

Shen, Y. 2012. Reconsidering English grammar teaching for improving non-English majors' English writing ability [Electronic version]. English Language Teaching, 5, 2012, $74-78$.

Sousa, D. A. 2011. How the ELL brain learns. California: Corwin.

Srinchanyachon, N. 2011. A comparative study of three revision methods in EFL writing [Electronic version]. Journal of College Teaching and Learning, 8, 2011, $1-8$.
Strickland, D. S., Galda, L., \& Cullinan, B. E. 2007. Language arts: Learning and teaching. USA: Thomson Wadsworth.

Tajzadeh, P., Khodadandehlou, M., \& Jahandar, S. 2013. The effect of grammar instruction on Iranian intermediate EFL learner's writing ability [Electronic Version]. Indian Journal of Fundamental and Applied Life Sciences, 5, 2013, 251 - 256.

Wasow, T. 2003. Generative Grammar. In M. Aronoff \& J. Rees-Miller (Eds.), The Handbook of Linguistics (pp 295 - 318). UK: Blackwell Publishing. 